\title{
UGLY TRANSLATIONS: ORTEGA Y GASSET'S IDEAS ON TRANSLATION WITHIN CONTEMPORARY TRANSLATION THEORIES
}

\author{
Pilar Ordóñez López \\ Universitat Jaume I - Espanha \\ mordonez@trad.uji.es
}

\begin{abstract}
This article is intended to provide a global vision of Ortega y Gasset's conception of translation and an integrative evaluation of his contribution to contemporary Western Translation Studies through the analysis of the role played by Ortega's views within the paradigms adopted in the most important approaches to translation in the $20^{\text {th }}$ century. The essay 'Misery and Splendour of Translation' brings together Ortega's ideas on translation, which, despite the recent orientation towards empirical and technical methods in Translation Studies, seem to be very much in evidence in current translation theories. This reveals the anticipatory character of Ortega's ideas, formulated in 1937.
\end{abstract}

Keywords: translation history, Ortega y Gasset, Translation Studies.

\section{Introduction}

José Ortega y Gasset (Madrid, 1883-1955) is considered one of the most outstanding and influential figures in $20^{\text {th }}$ century Spanish philosophy. His name is strongly associated with philosophy and politics. Nevertheless, a vast amount of references and reflection about language is scattered throughout his works. These recurrent references to language constitute what could be defined as Ortega's philosophical 'theory of language'. Translation occupies a significant position within this theory of language, and Ortega dedicated 
an essay to developing his ideas on translation. In 1937, he wrote 'Misery and Splendour of Translation', an essay that, as stated in previous works (Ordóñez-López, 2006), has attained the status of a "classic" of translation theory. However, it would be interesting to find out whether Ortega's ideas play an operative and active role in contemporary Translation Studies.

'Misery and Splendour of Translation' was first published in the Argentinian journal La Nación, in a series of five weekly articles, between June $13^{\text {th }}$ and July $11^{\text {th }}, 1937$. Taking into account the date of its publication, 'Misery and Splendour of Translation' can be included among early twentieth century translation theories. However, if the approach and tone of the essay are taken into consideration, one could undoubtedly classify it as a clear example of nineteenth century German Romanticism. In this sense, Ortega's approach to translation could be considered to be a mere continuation of the paradigms of German Romanticism. Notwithstanding, it is essential to acknowledge the innovative character of the essay within the Spanish context. It was Ortega's firm purpose, as he manifested/expressed himself on several occasions, to europeanise Spain, and the transfer of the ideas of German Romanticism to the Spanish context can be regarded as a way of influencing the country with European theories.

Despite the current trends, which are more empirical and practice-oriented, it is of vital importance to undertake the study of the history of translation, in order to provide the discipline with a humanistic dimension which, these days, is fundamental given the increasing orientation towards technical approaches in Translation Studies. An integrative and dynamic analysis of the historical dimension of the discipline will contribute to the development and consistency of Translation Studies.

\section{2. 'Misery and Splendour of Translation': Ortega's vision}




\section{of translation}

The essay 'Misery and Splendour of Translation' is structured as a fictitious dialogue held by academics and students of the Collège de France, in Paris. The essay is divided into five chapters: Chapter I, 'The Misery'; Chapter II: 'The Two Utopianisms'; Chapter III: 'About Talking and Keeping Silent'; Chapter IV: 'We Don't Speak Seriously'; and Chapter V: 'The Splendour'(1). Ortega's comprehensive exposition covers a considerable number of issues from a philosophical approach which is based, as previously mentioned, on figures from German Romanticism such as Goethe, Humboldt and Schleiermacher.

\subsection{The Miseries of Translation}

Ortega begins the discussion by explaining the 'miseries' of translation, as in his opinion admitting these miseries constitutes the necessary first step towards attaining the possible splendour of translation. On the path to splendour, Ortega tackles various aspects of language, which he conceives as the origin and source of knowledge and which takes a different shape according to each people's interpretation of reality.

Ortega begins by defining translation as a utopian activity, 'Isn't the act of translating necessarily a utopian task?' (Ortega y Gasset, 1992: 93). This utopian dimension is inherent, in Ortega's view, to every human endeavour. In the case of translation, the utopianism is due to the 'cowardice' of the translator who, according to the Spanish philosopher, would find him/herself incapable of rebelling against established language usage, inevitably betraying the original writer.

To write well is to make continual incursions into grammar, into established usage, and into accepted linguistic norms. It is an act of permanent rebellion against the social environs, a 
subversion. To write well is to employ a certain radical courage. Fine, but the translator is usually a shy character. [...] He finds himself facing an enormous controlling apparatus, composed of grammar and common usage. What will he do with the rebellious text? Isn't it too much to ask that he also be rebellious, particularly since the text is someone else's? He will be ruled by cowardice [...] he will betray him. Traduttore, traditore. (Ortega y Gasset, 1992: 94)

The utopianism of Ortega's vision of translation is mainly based on writers' personal style, formed by every author's personal deviations from habitual usage, as well as on what Humboldt called the 'internal form' of every language, which makes the complete correspondence of meanings between two languages impossible.

[...] it is utopian to believe that two words belonging to different languages, and which the dictionary gives us as translations of each other refer to exactly the same objects. Since languages are formed in different landscapes, through different experience, their incongruity is natural. It is false, for example, to suppose that the thing the Spaniard calls a bosque [forest] the German calls a Wald, yet the dictionary tells us that Wald means bosque. [...] an enormous difference exists between the two realities. (Ortega y Gasset, 1992: 96)

In this vein, Ortega also considers different degrees of difficulty in the possibility/impossibility of translating different types of texts; this he attributes -especially in the case of mathematics and the natural sciences - to the use of a specific terminology, considered by Ortega to be a 'pseudolanguage'.

A language is a system of verbal signs through which individuals may understand each other without a previous accord, while a terminology is only intelligible if the one who is writing or speaking and the one who is reading or listening have previ- 
ously and individually come to an agreement as to the meaning of signs. [...] That is why these books are easier to translate from one language to another. Actually, in every country these are written almost entirely in the same language. (Ortega y Gasset, 1992: 95)

\subsection{Attaining the Splendour}

It was most important that I emphasize the miseries of translating; it was especially important that I define its difficulty, its improbability, but not so as to remain there. On the contrary, it was important so that this might act as a ballistic spring to impel us toward the possible splendour of the art of translation. (Ortega y Gasset, 1992: 97)

In the three middle chapters of the essay, Ortega deals with several aspects related to the phenomenon of language, beginning by distinguishing two utopianisms, personalised in the good and the bad utopian:

Both the bad and the good utopians consider it desirable to correct the natural reality that places men within the confines of diverse languages and impedes communication between them. The bad utopian thinks that because it is desirable, it is possible. [...]The good utopian, on the other hand, thinks that because it would be desirable to free men from the divisions imposed by languages, there is little probability that it can be attained; therefore, it can only be achieved to an approximate measure. But this approximation can be greater or lesser, to an infinite degree, and the efforts at execution are not limited, for there always exists the possibility of bettering, refining, perfecting: "progress", in short. (Ortega y Gasset, 1992: 98-99) 
As already suggested by the previous quotation, 'talking' is also a utopian action, as language constitutes an 'unsurmountable obstacle' (Ortega y Gasset, 1992: 101) to the expression of our thoughts which, besides, are already 'in great measure attributable to the tongue' (Ortega y Gasset, 1992: 102). Therefore, we are doubly limited by our own language.

\begin{abstract}
[...] when speaking or writing we refrain constantly from saying many things because language doesn't allow them to be said. The effectiveness of speech does not simply lie in speaking, in making statements, but, at the same time and of necessity, in a relinquishing of speech, a keeping quiet, a being silent!. (Ortega y Gasset, 1992: 103)
\end{abstract}

Silence is an essential element in Ortega's conception of language, which actively participates in the act of translating. Silence consists of two different levels (Ordóñez-López, 2006: 7071), and it is considered an inherent and crucial component of every language. Silence shapes each language differently, so that 'each language is a different equation of statements and silences' (Ortega y Gasset, 1992: 104). It is precisely here that the main difficulty of translation lies. Nevertheless, in the philosopher's dual vision of translation, silence also conveys the possible splendour of translation which, in Ortega's humanistic vision, consists in 'the revelation of the mutual secrets that peoples and epochs keep to themselves and which contribute to their separation and hostility; in short - an audacious integration of Humanity'(Ortega y Gasset, 1992: 104).

Furthermore, Ortega considers language to be the origin and the embryonic element of all types of knowledge. This 'first knowledge' (Ortega y Gasset, 1992: 107) originally reflected the truth about the world and the differentiations established to the 'limitless continuum of diversity of reality' (Ortega y Gasset, 1992: 106) by different peoples. 
The consideration of language and, inevitably, silence as crucial obstacles to translation is the only way to be able to attain the possible splendour of translation.

\subsection{The Splendour of Translation}

Ortega concludes his essay with a discussion about the splendour of translating. In this chapter he describes what he understands by translation and how translators should proceed. Ortega acknowledges that "what is essential concerning the matter has been said more than a century ago by the dear theologian Schleiermacher' in his work Über die verschiedenen Methoden des Übersetzens (1813). Ortega contemplates the two possible methods of translation proposed therein: 'Either the translator leaves the writer alone as much as possible and moves the reader toward the writer, or he leaves the reader alone as much as possible and moves the writer toward the reader' (Ortega y Gasset, 1992: 108). However, Ortega's position is categorical: only when we tear the reader away from his native linguistic conventions and force him to throw himself into the mind of the original author can we speak of 'translation proper' (Ortega y Gasset, 1992: 108). This is the procedure to be followed by the 'shy' translator.

Ortega then proceeds to establish some principles that should govern the 'the new enterprise of translating' (Ortega y Gasset, 1992: 108) and define what a translation should be:

Translation is not a duplicate of the original text [...] translation doesn't even belong to the same literary genre as the text that was translated [...] translation is a literary genre apart $[\ldots]$ with its own norms and own ends [...] a translation is not the work, but a path toward the work [...] I imagine a form of translation that is ugly, as science has always been; that does not intend to wear literary garb; that is not easy to read, but is very clear indeed. (Ortega y Gasset, 1992: 109, 111) 
In order to achieve this form of translation, Ortega claims, it would be necessary to make 'divergent translations of the same work' (Ortega y Gasset, 1992: 111), as it would not be possible to approximate all the facts of the original text at the same time.

Having presented his conception of translation, Ortega points out the need to restore the prestige of this activity, and he proposes that it should be enhanced by recommending its practice to writers.

In general, no writer should denigrate the occupation of translating, and he should complement his own work with some version of an ancient, medieval, or contemporary texts. It is necessary to restore the prestige of this labor and value it as an intellectual work of the first order. Doing this would convert translating into a discipline sui generis which, cultivated with continuity would devise its own techniques and would augment our network of intellectual approaches considerably. (Ortega y Gasset, 1992: 111-112)

This is an undeniably positive prospect for translation, but it is only attainable if 'in translating, we try to leave our language and go to the other' (Ortega y Gasset, 1992: 112), which is what has been done in the German translation of his works. This way, the reader finds him/herself making mental turns that occur naturally in the source language.

\section{Translation Theories}

Due to technological progress and the development of international relations, the twentieth century can be considered the era of translation. In the first half of the century, reflection on translation received an increasing amount of attention. During this period works tend to be rooted in a philosophical vision of language, inherited from German Romanticism. In broad terms, works from the early 
twentieth century lack terminological accuracy in their reference to translation concepts. Only during the second half of the century did scholars begin to call for a more systematic and descriptive study of the act of translating.

The interdisciplinary nature of translation, a discipline situated between languages, cultures and other disciplines such as literature and linguistics, is reflected in contemporary Translation Studies. In translation literature, we can find various co-existing approaches, depending on the different perspectives adopted by scholars in their reflections and on the element of the translation process they focus on. Hurtado Albir (2001: 125-132) classifies the main theoretical approaches into five conceptual blocks (2): 'Linguistic theories', 'Textual theories', 'Cognitive theories', 'Communicative and Socio-cultural theories', and 'Philosophical and Hermeneutic theories'.

'Linguistic theories' are based on the application of a specific linguistic model and the idea that any translation theory should be built on a certain theory of language. The two languages involved in every act of translating are described and compared. Within these theories, different approaches can be distinguished, depending on the linguistic model applied. Amongst others, authors such as Vinay and Darbelnet, Catford and Vázquez Áyora can be included within this group.

'Textual theories' argue that translation is a textual process and incorporate into their interpretations of the act of translating aspects such as macro-structure, micro-structure, intertextuality, etc., depending on applied taxonomy. Within these theories names such as Ladmiral, House, Neubert and Hatim and Mason can be highlighted.

'Cognitive theories' are those focusing on the analysis of the mental process made by translators. Within the framework of psycholinguistics applied to translation, scholars intend to 'establish how translators and interpreters process information, both as distinct from other speakers and writers and as distinct from each other' (Bell, 1998: 185). This approach can be found in work by scholars such as Delisle, Wilss, Kussmaul and Kiraly. 
'Communicative and Socio-cultural theories' place the emphasis on the communicative function of translations, taking into consideration all contextual aspects surrounding a translation and emphasizing the relevance of cultural elements as well as the role of the translations' readers. According to Mason, in communicative and socio-cultural theories 'the context of situation is crucial and must include the participants in speech events, the action taking place and other relevant features' (Mason, 1998: 29). The translator should proceed then to make any required adjustment in order to achieve appropriateness in the different contexts and uses involved. Scholars such as Nida and Taber, Toury, Reiß and Vermeer, and Nord can be included in the list of those embracing this approach.

'Philosophical and Hermeneutic theories' are those that focus on the hermeneutic nature of translation and the philosophical aspects therein. According to Robinson, these theories involve 'an empathic projection of the interpreter's desire to understand into the activity s/he is attempting to understand' (Robinson, 1998: 97). Hermeneuts, therefore, 'imagine themselves inside the activity [...] and attempt to describe what they find from within' (Robinson, 1998, 97). This approach is adopted by Berman, Steiner, Gadamer, Venuti and Ortega Arjonilla.

\section{Ortega in Contemporary Translation Theories}

The results obtained in an earlier work (Ordóñez-López, 2006) provide some background information for this analysis. Ortega's essay 'Misery and Splendour of Translation' has been considered by some of the most outstanding scholars to be one of the most representative examples of reflection on the topic within its period. At the same time, in the various chronological divisions of the history of translation theory established by different scholars (OrdóñezLópez, 2006: 196-197, 241-243), Ortega's work has been described 
as a philosophical reflection, characterised by its speculative nature and lack of empirical evidence and specialised terminology. Taking these results into account, it is only logical to anticipate a closer connection between Ortega's views and philosophical and hermeneutic approaches, while a considerable distance between his ideas and those developed in linguistic and textual approaches can be expected. However, it is interesting to explore the impact of the essay on the main theoretical approaches individually, from the second half of the twentieth century to the present day.

\subsection{Ortega in Linguistic Theories}

According to Fawcett (1998: 120), 'the relationship of linguistics to translation can be twofold: one can apply the findings of linguistics to the practice of translation, and one can have a linguistic theory of translation'. The second approach is found in Catford, who in A Linguistic Theory of Translation, An Essay in Applied Translation (1965) intends to define translation in terms of a linguistic theory. In order to provide a fair and accurate interpretation of Catford's theory, we must take into consideration the date his work was published, which was prior to the consolidation of Applied Linguistics. Catford's work lacks an integrative vision of language, remaining on the sentence level and thus leaving aside any further elements embedded in a text, viewed as a unit, in the framework of communication.

Translation is an operation performed on languages: a process of substituting a text in one language for a text in another. (Catford, 1965: 1)

With this definition in mind, Catford's linguistic theory of translation is formulated by means of several categorisations in which he reflects on the different types of translation and the main aspects therein: full vs. partial translation (1965: 21), total vs. restricted 
translation (1965: 22), rank-bound vs. unbounded translation (1965: 24-25), textual equivalence (1965: 27) vs. formal correspondence (1965: 27), and substitution vs. transference (1965: 48).

Catford's theory of translation is based on the abovementioned categories and concepts, and is characterised by a predominantly empirical perspective that remains at the sentence level. Furthermore, Catford's vision of translation is extremely fragmented, as shown by the detailed divisions applied to the act of translation, distinguishing between phonological translation (1965: 52), graphological translation (1965: 63), transliteration (1965: 66) and grammatical and lexical translation (1965: 71). All these categories stand in contrast to the so-called 'total translation', which is the most relevant category regarding our purpose here:

In total translation, the question of "sameness" of situationsubstance is a difficult one, and is linked to the question of "sameness" or otherwise of the cultures (in the widest and loosest sense) to which SL and TL belong. (Catford, 1965: 52)

Catford does, however, acknowledge the limits of total translation. Notwithstanding, these appear to be fairly flexible and inevitably bounded to other non-necessarily linguistic elements, such as situation or function:

Translation fails - or unstranslatability occurs - when it is impossible to build functionally relevant features of the situation into the contextual meaning of the TL text. Broadly speaking, the cases where his happens fall into two categories. Those where the difficulty is linguistic, and those where it is cultural. (Catford, 1965: 94)

It is obvious that Catford's views differ considerably from Ortega's, especially due to the lack of empirical perspective which characterises his essay. Nevertheless, despite the totally divergent 
perspectives adopted by these two authors, a convergence can be observed with regard to the aspects they consider to be involved in the translation process, such as correspondence, equivalence, transfer, translatability, etc. It is also interesting to point out that almost forty years later, Catford's work still lacks a specialised jargon, though a shift towards a more empirical and descriptive approach which would be taken up increasingly from the next decade onwards - can already be observed.

\subsection{Ortega in Textual Theories}

Textual approaches are derived from an empirical perspective applied to linguistics. In these approaches a practical application of linguistics to translation has given rise to different categorisations and taxonomies which are used to describe the process of translation and the procedures followed by translators, on the basis of the notion of equivalence.

Scholars working within these approaches intend to demonstrate the relevance of a componential analysis of translation. More integrative perspectives have progressively been incorporated: word and phrase level taxonomies have been broadened in order to take into consideration other relevant and essential aspects such as register, discourse or function, i.e. Hatim and Mason (1990, 1997) and Baker (1992).

As an example of textual approaches, we have selected Ladmiral's work, Traduire: Theorèmes pour la traduction (1979). Despite his textual approach to translation and the chronological gap between Ladmiral and Ortega's work, foundational similarities can be found between them. Ladmiral defines translation as a universal and human activity, thus adopting a similar starting point as Ortega. With a more specialised jargon, due to the incorporation of theoretical findings and the consolidation of translation studies as a discipline sui generis, Ladmiral adopts an unequivocally human perspective. Consequently, his global conception of translation bears a great degree of analogy to that provided by Ortega in 1937: 
Non seulement il peut-être difficile d'abstraire la parole de l'auteur de la langue-source au sein de laquelle elle a trouvé sa formulation, mais surtout la solidarité de chaque langue avec tout un contexte culturel fait apparaitre la nécessité d'intégrer à la théorie de la traduction la perspective extra-linguistique [...]. Dans la pratique la traduction sera bien sûr toujours partielle. Comme toute acte de communication, elle comportera un certain degré d'entropie, autrement dit une certaine déperdition d'information. (Ladmiral, 1979 : 17-19) (4)

Furthermore, Ladmiral reflects on the possibility or impossibility of translation in this work, analysing the ideas of du Bellay, Mounin and Meschonnic amongst others. According to Ladmiral, however, the antagonistic character of translation can be explained by the deep cleavage between the theoretical and practical sides of this activity:

Ce ne sont pas les memes personages qui theórisent (l'impossibilité) et qui traduissent [...] Ce clivage est particulièrement net en traduction [...] le prolétariat des traducteurs «sur le terrain» est maintenu à l'écart de la contemplation théorique. Cette dernière est l'apanage d'une aristocratie de linguistes qui philosophent sur la traduction, dont ils n'ont pas la pratique. (Ladmiral, 1979 : 90) (5)

With these statements in mind, Ladmiral carries out an analysis of the act of translating, built upon the classical opposition between denotation and connotation, focusing on the different dimensions of the latter:

Les connotations constituent un fait linguistique collectif, ni purement individuel ni non plus totalement général ou universel, à vrai dire intermédiaire entre la parole et la langue, mais plus proche de cette dernière. (Ladmiral, 1979 : 145) (6) 
Though Ladmiral's style of writing is more specialized, these dimensions are already latently present in Ortega's discussion on the non-existence of exact synonyms, illustrated by his example of the German word 'Wald' and the Spanish 'bosque' (see 2.1.).

A clear divergence, however, can be observed in regard to the recommended translation procedures proposed by these two authors, in spite of their shared recognition of the relevance of source language and culture. On the one hand, we have Ortega's categorical translation proposal, which can be classified as pure foreignisation; on the other hand, Ladmiral's attitude reveals a more flexible and empirical perspective.

[...] le traducteur est conduit à explorer, de proche en proche, tout un paradigme paraphrastique d'équivalents quasi ou parasynonymiques, mais c'est pour prendre la mesure des différences ou des nuances qui les distinguent. En ce cas, les choix de traductions sont dictés par le sens même du textesource et non plus seulement par les contraintes plus ou moins aléatoires de l'ajustement contextuel coextensive à l'écriture d'un texte-cible. (Ladmiral, 1979: 169-170) (7)

\subsection{Ortega in Cognitive Theories}

Translation Studies has traditionally focused on the product, this is, the translation, rather than on the process of translating itself. However, with the development of cognitive and psycholinguistic approaches, the emphasis has shifted to the process of translation. This shift implies a turn towards an empirical approach to translation, which is relatively new and aims to establish what goes on in the translator's mind while he/she undertakes the task of translation. Cognitive theories integrate aspects such as understanding, learning and mental representations, and they have contributed significantly to translation training. Most contemporary cognitive theories analysing the process of translation have been carried out on 
the basis of empirical studies such as the Think Aloud Protocol (TAPs) methodology.

Kiraly, in his work Pathways to Translation: Pedagogy and Process (1995), adopts a double perspective in his analysis of translation: first, he considers translation as a social and communicative activity; secondly, he regards translation as a cognitive activity.

Furthermore, Kiraly intends to relate translation theory to translation training. He highlights the importance of 'the development of the discipline of translation studies for investigation of the cognitive processes involved in translation' (1995: 47). His aim is to investigate how the process of translation and the necessary competences it involves can be understood, and how they can be manipulated in order to train more creative, confident and competent translators.

Kiraly's cognitive model attempts to represent the cognitive system which is activated during the process of translation, based on empirical evidence gleaned from his case studies. His model consists of three main aspects: information sources (1995: 100-105), intuitive working space, and think control centre. Kiraly postulates the existence of an intuitive working space, where the information stored in the short-term memory mixes with the information provided in the text and the external resources without any conscious control. Within this working space, two types of products arise: the draft translation and the translation problems. In target language control, the subject (or translator), uses the stored rules of the target language, contrasting them with the elements of the draft translation in terms of their syntactic adequacy and semantic accuracy. Translation problems arise within the intuitive working space when the automatic processing does not produce any provisional translation for certain elements.

This model is accompanied by Kiraly's case study, using a TAPs methodology, which consists of an introspective technique according to which the studied subjects are asked to translate a text and utter simultaneously everything that goes on in their minds while they are translating. 
Ortega's views on translation lie far from current cognitive approaches. Ortega's description of the translator as 'a shy character [...] facing an enormous controlling apparatus, composed of grammar and common usage [who] will be ruled by cowardice' (Ortega y Gasset, 1992: 94) has now been surmounted by the conception of the translator as an active and operative agent in the process of translation, whose mental activity while translating conveys relevant information to the improvement of translation training and therefore, ultimately, the quality of translations.

\subsection{Ortega in Communicative and Socio-cultural theories}

In communicative and socio-cultural approaches, the focus lies on the specific situation in which the text or translation is embedded. At the same time, the situation is regarded as an integrative part of a specific society or culture. Language must, thus, be considered part of a culture. Within this approach, the Skopos Theory (Skopostheorie) has played an outstanding and leading role. This theory is built upon concepts such as skopos (purpose), equivalence/ adequacy, function, culture and text-type. With Möglichkeiten und Grenzen der Übersetzungskritik (1971), Katharina Reiß (3) made a significant contribution to translation studies by proposing a new model of translation based on the functional relationship between source and target texts, and developing a text typology that takes into account not only the subject matter but also the function of the particular text type (1971: 32).

Skopos Theory offers an alternative to traditional translation theories. Reiß and Vermeer, in Grundlegung einer allgemeinen Translationstheorie (1984), explain the key aspects of their translation model. With a philosophical foundation, language is considered an instrument of knowledge on the one hand and on the other hand, a communicative and social instrument, integrated on several levels. The Skopos Theory is based on the following rules: 
1. A TT is determined by its Skopos

2. A TT is an offer of information in a TC and TL concerning an offer of information in a SC and SL

3. A TT is not clearly reversible

4. A TT must be internally coherent

5. A TT must be coherent with the ST

According to the Skopos Theory, what translators should do is produce texts that are at least likely to be meaningful to the target readers; therefore, a translation can only be regarded as successful if the reader is able to understand it and regard it as coherent with his/her situation.

Departing from tradition as well as from other approaches that consider translation a more systematic activity, this approach presumes that the same text can be translated in different ways, depending on the communicative function of the target text. This echoes Ortega's recommendation to produce 'divergent translations of the same work' (Ortega y Gasset, 1992: 111), since it is impossible to approach all dimensions of the texts as the same time, as Ortega implies. In general, communicative and socio-cultural approaches bear a certain degree of similarity to Ortega's ideas, as they incorporate some theoretical and communicative aspects tackled by the philosopher, although there is a clear divergence regarding the way these aspects are dealt with in $20^{\text {th }}$ century translation literature.

Despite the many differences existing between the dominant functional approaches and Ortega's ideas, such as the empirical dimension, the use of a specialised terminology and the active role of the translator, it is important to note the fundamental role played by function in Ortega's views on translation. According to his vision, the main purpose of translation is to re-educate people on the basis of Roman and Greek ancient civilisations. His categorical proposal of foreignising translation can primarily be understood an extreme attempt to achieve this, as it is only through foreignising translation that readers can gain a genuine understanding of those civilisations, appreciate differences and learn from them. 


\subsection{Ortega in Philosophical and Hermeneutic theories}

As previously mentioned, it is only natural to expect a closer connection between Ortega's ideas on translation and philosophical and hermeneutic approaches. Hermeneutic theories enable the translator to approach the text from where he/she stands, rather than from the position of the original author; as the hermeneutic notion of translation begins with the translator's understanding of the text, there is no meaning without understanding.

One of the authors most representative of hermeneutic approaches is Steiner with his work After Babel: Aspects of Language and Translation (1977). As a hermeneut, Steiner aims to explore translation from the inside, and he integrates recent work on translation with views taken from German Romanticism.

From the very beginning, it is impossible to ignore the parallels between Steiner's and Ortega's perspectives. This parallelism is especially obvious with regards to the view that translation is an activity which is implicit in every act of speech. Steiner argues that translation, understood as the interpretation of verbal or written signs in one language by means of verbal or written signs in another, is an accentuated case of the process of communication; thus a 'theory of translation' is necessarily a theory of language.

The model "sender to receiver" which represents any semiological and semantic process is ontologically equivalent to the model "source-language to receptor-language" used in the theory of translation. (Steiner, 1992: 49) (8)

However, Steiner's explanation contains a more elaborate analysis both regarding the aspects involved and the terminology. Elements such as time (regarded as a chronological influence), society (regarded as a cultural influence) and personal speech play an essential role in Steiner's views on translation. Following these considerations, Steiner begins his analysis of translation by taking language as the starting point. Language is conceived as gnosis, as 
a social, historical and personal phenomenon. In his analysis, Steiner acknowledges the fundamental role of silence; this represents another point of overlap with Ortega's ideas:

In actual speech all but a small class of definitional or "unreflective-response" sentences are surrounded, mutely ramified, blurred by an immeasurably dense, individualized field of intention and withholding [...] Human speech conceal far more than it confides; it blurs much more than it defines, it distances more than it connects. (Steiner, 1992: 240)

Steiner also reflects on the possibility of translation, quoting Ortega's declaration of impossibility. Despite this quote, he adopts a more optimistic position, as the 'impossible is overcome at every moment in human affairs' (Steiner, 1992: 264), so that there are no practical implications. Furthermore, according to Steiner, the focus should be shifted from the impossibility itself to the 'degree of fidelity to be pursed in each case' (Steiner, 1992: 264).

Steiner's views on translation are presented using a similar approach to that of 'Misery and the Splendour of Translation'. Nevertheless, Steiner's hermeneutic conception of translation is presented by means of a detailed description of the translation act in terms of hermeneutic motion, consisting of four progressing stages: trust, penetration, embodiment and restitution (Steiner, 1992: 312320). In broad terms, Steiner presents a hermeneutic model which is applied to translation, whereas Ortega's reflections remain less specific level, the application of hermeneutics to language at a more general level.

Despite the theoretical character of his work, Steiner's approach to translation maintains a closer relation to the practice of translation than that of Ortega. This can be appreciated in Steiner's discussion about what is 'perfect' in translation and how to deal with the attainment of this perfection in the practical context of translation. 
A "perfect" act of translation would be one of total synonymity. It would presume an interpretation so precisely exhaustive as to leave no single unit in the source text -phonetic, grammatical, semantic, contextual- out of complete account, and yet so calibrated as to have added nothing in the way of paraphrase, explication or variant. But we know that in practice this perfect fit is possible neither at the stage or interpretation nor at that of linguistic transfer and restatement [...]. (Steiner, 1992: 428)

\section{Conclusion}

The consolidation of Translation Studies as an academic discipline has led to the development of a more empirical framework of theoretical approaches to translation, focusing more on the practical context of translation than on reflection of a more philosophical nature.

Similarly, issues which provoked continued controversy during earlier, philosophically oriented stages, such as the oppositions between literal and free translation and translatability vs. untranslatability, seem to have been overcome.

Current translation studies benefit from the development of other, related disciplines such as psycholinguistics and other cognitive sciences, which have allowed for a more in-depth analysis of the translation process. As a result of this, the role of the translator has become a considerably more active one, as reflected in the approaches to translation analysed in this study.

Nevertheless, Ortega's views on translation are still relevant within current Translation Studies, not only because some of the aspects he discussed have been further developed, but also because it is necessary to understand the historical dimension of the discipline. Although Ortega's proposals in favour of foreignisation and 
ugly translations has not been adopted in current theories, Ortega's approach to translation bears considerable resemblance to some of the most representative names in translation literature. It is also important to note the varying degree of relevance of his essay depending on the specific approach.

This study reveals an uneven picture in terms of the influence of Ortega's views on the different translation approaches, but it is nevertheless clear that 'Misery and Splendour of Translation' has, amongst other classical works, made a noticeable contribution to the creation of a solid foundation for the subsequent development of Translation Studies.

\section{Notes}

1. 'Misery and the Splendor of Translation', translated by Elizabeth Gamble Millar and edited by R. Schulte and J. Biguenet in Theories of Translation: An Anthology of Essays from Dryden to Derrida, Chicago and London: The University of Chicago Press, 1992, pp. 93-112.

2. It should however be noted that nowadays, according to Hurtado Albir (1994: 32), a more restrictive stage has been left behind, leading to more comprehensive approaches to translation. As a result of this, a significant degree of interconnection between the abovementioned theories can be observed in translation literature today.

3. It should also be noted that Katharina Reiß is the author of one of the two existing version of the essay into German: Reiß, K., Elend und Glanz der Übersetzung, Munich: dtv zeispraching, 1976. Furthermore, Reiß has provided several works dedicated to the analysis of Ortega's views on translation.

4. Our translation: Not only can it be difficult to distinguish between the author's language usage and the language from which the former has derived its formulation, but furthermore, the solidarity of each language with its cultural context makes 
it necessary to incorporate an extra-linguistic perspective into theory of translation [...]. In practice, translation will, of course, always be partial. As any act of communication, translation will imply a certain degree of entropy, in other words, a certain loss of information.

5. Our translation: The people who theorise (impossibility) are not the same as those who translate [...] This gap is particularly obvious in the area of translation [...] the proletarian translators 'on the ground' are kept well away from theoretical reflection, which is a priviledge of an aristocracy of linguists who philosophise about translation, which they don't practise.

6. Our translation: Connotations are a collective linguistic fact which is not purely individual but not totally general or universal either; the truth is that they are halfway between parole and langue, but closer to the latter.

7. Our translation: $[\ldots]$ the translator is led to explore, little by little, a shole paraphrastic paradigm of quasi -or parasynonimous equivalents, but the purpose is to become aware of the differences or nuances that distinguish them. In this sense, the choices of translation are dictated by the meaning of the source-text and not only by the more or less random constraints imposed by the contextual adjustement which corresponds to the style of the target-text.

8. Here an important similarity can be observed to Ortega's definition of speech, in which talking is considered a utopian activity (Ortega y Gasset, 1992: 101), as well as Ortega's hermeneutic theory of language (Ordóñez-López, 2006: 45-95).

\section{Bibliography}

BAKER, M. In Other Words: A Coursebook on Translation, London/New York: Routledge, 1992. 
BAKER, M. (ed.), Routledge Encyclopedia of Translation Studies, London: Routledge, 1998.

BELL, R.T., 'Psycholinguistic/Cognitive Approaches', in Baker, M. (ed.), Routledge Encyclopedia of Translation Studies, London: Routledge, 1998, pp. 185-190.

BERMAN, A., L'épreuve de l'étranger. Culture et traduction dans l'Allemagne romantique, Paris : Gallimard, 1984 (The Experience of the Foreign Culture. Translation in Romantic Germany, New York : State University of New York Press, 1992).

CATFORD, J.C., A Linguistic Theory of Translation: An Essay in Applied Linguistics, London: Oxford University Press, 1965.

DELISLE, J., L'Analyse du discours comme méthode de traduction, Cahiers de Traductologie 2, Otawa : Éditions de l'Université d'Otawa, 1980 (Translation : An Interpretative Approach, Otawa : University Press, 1988).

FAWCETT, P., 'Linguistic Approaches', in Baker, M. (ed.), Routledge Encyclopedia of Translation Studies, London: Routledge, 1998, pp.120-125.

GADAMER, H.G., Truth and Method, London: Sheed and Ward, 1975.

HATIM, B. and Mason, I., Discourse and the Translator, London/New York: Longman, 1990.

HATIM, B. and Mason, I., The Translator as Communicator, London: Routledge, 1997.

HOUSE, J., A Model for Translation Quality Assessment, Tübingen: Gunter Narr, 1977.

HURTADO Albir, A., 'Perspectivas de los estudios sobre traducción', in Hurtado Albir, A. (ed.), Estudis sobre la traducció, Castelló: Publicaciones de la Universitat Jaume I, D.L., 1994, pp. 25-41. 
HURTADO Albir, A., Traducción y traductología: introducción a la traductología, Madrid: Cátedra, 2001.

KIRALY, D.C., Pathways to Translation: Pedagogy and Process, Kent: Kent State University, 1995.

KUSSMAUL, P., Training the Translator, Amsterdam: John Benjamins, 1995.

LADMIRAL, J.R., Traduire: Theorèmes pour la traduction, Paris: Payot, 1979.

MASON, I., 'Communicative/Functional Approaches', in Baker, M. (ed.), Routledge Encyclopedia of Translation Studies, London: Toutledge, 1998, pp. 29-33.

NEUBERT, A., Text and Translation, Leipzig: VEB Verlag Enzyklopädie, 1985.

NEWMARK, P., Approaches to Translation, Oxford: Pergamon, 1981.

NIDA, E.A. and Taber, C., The Theory and practice of Translation, Leiden: E.J. Brill, 1969.

NORD, C., Textanalyse und Übersetzen, Heidelberg: J. Groos Verlag, 1988 (Text Analysis in Translation, Amsterdam: Rodopi, 1991).

ORTEGA Arjonilla, E., Apuntes para una teoría hermenéutica de la traducción, Málaga: Universidad de Málaga, 1996.

ORDÓÑEZ López, P., 'Miseria y esplendor de la traducción': La influencia de Ortega y Gasset en la traductología contemporánea, Doctoral Thesis, 2006.

ORTEGA Y GASSET, J., 'Misery and Splendor of Translation' in Schulte, R., Biguenet, J., Theories of Translation: an Anthology of Essays from Dryden to Derrida, Chicago: University of Chicago Press, 1992, pp. 93-112. Translated by Elizabeth Gamble Miller. 
REIß, K., Möglichkeiten und Grenzen der Übersetzungskritik, München: Hueber, 1971.

REIß, K., Vermeer, H., Grundlegung einer allgemeinen Translationstheorie, Tübingen: Niemeyer, 1984.

ROBINSON, D., 'Hermeneutic Motion', in Baker, M. (ed.), Routledge Encyclopedia of Translation Studies, London: Routledge, 1998, pp. 96-99.

STEINER, G., After Babel: Aspects of Language and Translation, Oxford: Oxford University Press, 1992 [1977].

TOURY, G., Descriptive Translation Studies - and beyond, Amsterdam: John Benjamins, 1995.

VÁZQUEZ AYORA, G., Introducción a la Traductología, Washington: Georgetown University Press, 1977.

VENUTI, L., The Translator's Invisibility. A History of Translation, London: Routledge, 1995.

VINAY, J.P. and Darbelnet, J., Stylistique comparée du français et de l'anglais. Méthode de traduction, Paris: Didier, 1958 (Comparative Stylistics of French and English. A Methodology for Translation, Amsterdam: John Benjamins, 1995.

WILLS, W., Übersetzungwissenschaft: Probleme und Methoden, Stuttgart: E. Klett, 1977 (The Science of Translation. Theoretical and Applicative Aspects, Tübingen: Gunter Narr, 1982). 